\title{
Awareness, Training Needs and Constraints on Fishing Technologies among Small Scale Fishermen in Ondo State, Nigeria
}

\author{
Joshua Babatunde Ogunremi ${ }^{1}$ \\ ${ }^{1}$ Department of Biological Sciences, Ondo State University of Science and Technology, Nigeria \\ Correspondence: Joshua Babatunde Ogunremi, Department of Biological Sciences, Ondo State University of \\ Science and Technology, Nigeria. Tel: 234-810-265-0455. E-mail: jogunremi@gmail.com
}

Received: February 25, 2016

Accepted: April 15, 2016 Online Published: May 15, 2016

doi:10.5539/jas.v8n6p169

URL: http://dx.doi.org/10.5539/jas.v8n6p169

\begin{abstract}
The role of fishing technologies in achieving the National goal of food sufficiency cannot be over emphasized. Many small scale fishermen who are supposed to be the end users of various modern fishing technologies are ignorant of various technological opportunities they stand to gain in their profession. Therefore, the objective of the study was to determine the awareness, training needs and constraints on fishing technologies among small scale fishermen in Ondo State, Nigeria. A multistage random sampling procedure was employed to select three local Government areas (Irele, Ilaje and Ese-odo), six fishing communities, and twelve artisanal fishermen to get a sample size of 216. Data were collected from the respondents using structured interview schedule and analyzed through the use of descriptive and inferential statistical tools. The results revealed that most of the artisanal fishermen were aware of the fishing technologies and $82.4 \%$ indicated favourable training needs towards fishing technologies. Major constraints experienced by the respondents were lack of proper net maintenance (76.9\%), limited outboard engine repair workshop (73.6\%) and effective fish processing, preservation techniques and equipment (70.4\%). Significant relationship existed between awareness and training needs on fabrication of low cost fishing gears $\left(\chi^{2}=18.48 ; \mathrm{p}<0.00\right)$, smoking oven $\left(\chi^{2}=15.77 ; \mathrm{p}<0.00\right)$ and outboard engine repairs $\left(\chi^{2}=\right.$ 5.47; $\mathrm{p}<0.01)$. Based on the findings of the study, concerted efforts should be made by all stakeholders to ensure that the required training needs of artisanal fishermen are met for the sustenance of fisheries technologies.
\end{abstract}

Keywords: artisanal fishermen, fishing technologies, training needs

\section{Introduction}

Nigeria like any other developing countries is in dare need to meet up fast with the rest of developed world in fish production hence, on recognition of the great potentials of small scale fishing in Nigeria, government is making all necessary efforts to ensure that appropriate technologies are made available to fishermen through adequate training which will reduce fish spoilage, increase catches and on the long run improve the livelihood of the fishermen.

Any attempt at defining distinctive characteristics for subsistence, artisanal and traditional small scale fishers is inevitably faced with the overlapping and shifting nature of these fisheries and this makes any one definition difficult (Sunde \& Pedersen, 2007). Definitions and terminologies differ, are often ambiguous, and are also not used consistently (FAO, 2005; O'Riordan, 2005; Branch, 2005; Hauck, 2000). The use of the term 'small-scale fishers' as defined is a more developmental approach to management, as it will allow for growth and entrepreneurship within the sector, enabling fishers to increase their capacity to engage with the market and move into more lucrative ventures. Fishers will not be 'locked' into a definition that precludes them from adding value to the resources that they rely on for livelihood purposes, irrespective of whether these resources are perceived as high or low value resources (Sunde \& Pedersen, 2007).

The 'cut off' criterion for small-scale or traditional and industrial varies according to national characteristics of the fisheries. In some cases, size of boat or engine power defines the cut off, and in other cases the zone prioritized and set aside for the artisanal/small-scale is the determining criterion, e.g. in Guinea Bissau where the first 6 nautical mile zone is exclusively for small-scale fishing (O'Riordan, 2005). The variance in scale incorporated in definitions used in the African context is confirmed by Sowman (Sowman, 2004). Whether previously regarded as 'subsistence', 'artisanal' or 'limited commercial', all small-scale fishers require a similar 'enabling policy' and management approach. This enabling policy will provide the mechanisms to ensure that the 
fishers can engage with and benefit from new opportunities. Therefore, it is anticipated that these fishers will need infrastructure, training and on-going support. Towards this end there is a need for integration with local economic development strategies (LED) (Sunde \& Pedersen, 2007). Extensive work undertaken by the FAO has led to the development of guidelines for an enabling policy environment for the small-scale sector (FAO COFI, 2005).

Training is thus concerned with people-on-jobs in organizations. This implies that training is primarily concerned with preparing the participant for certain lines of action, which are delineated by technology and by the organization in which he works. Training therefore, helps the participant improve his job. This is the essence of extension services. Training essentially deals with understating and skill (Adeokun \& Adereti, 2005). An extension training programme carried out by qualified staff of a well organized advisory service, in cooperation with extension and research staff in the field and backed up by responsible official, is a most effective means through which the farmers (fish workers) become aware of their problem and learn skills for their involving rural people in practical demonstration to enhance training in areas of their need (Adeokun \& Adereti, 2005).

\subsection{Problem Statement}

The emphasis all over the world is the proper application of technologies for higher productivity in agriculture of which fishing is a sub set. For this to be a reality, it is imperative to create awareness and train the small scale fishermen who are the end users on various fishing technologies. Therefore, the general objective of this research was to determine the awareness, training needs and constraints on fishing technologies among small scale fishermen in Ondo State, Nigeria.

\subsection{Specific Objectives of the Study}

(i) Identify awareness of fishing technologies among small scale fishermen;

(ii) Determine the training needs of small scale fishermen;

(iii) Examine the constraints experienced by the small scale fishermen.

\subsection{The Hypothesis}

There is no significant relationship between the awareness of fishing technologies among small scale fishermen and training needs in the study area.

\section{Methodology}

\subsection{Sampling Method}

The research was conducted in the Coastal areas of Ondo State, Nigeria. Three local Governments (Irele, Ilaje and Ese-odo) were selected for the study because of the major fishing activities in the area. A multistage random sampling technique was employed to select six fishing communities from each Local government and twelve small scale fishermen were randomly selected from each of the communities.

\subsection{Sampling Size}

A total sample size of 216 fishermen were implored in the research.

\subsection{Research Design}

Data were collected from the respondents using structured interview schedule and analyzed through frequency counts and percentages, to describe the awareness of small scale fishermen on fishing technologies and perceived needs for training. Chi-square was used to determine the relationship between the independent variables and training needs of fishermen on fisheries technologies.

\section{Results and Discussion}

The fishermen have high awareness on all the fishing technologies as shown in Table 2 designing multiple hooks on a line $90.3 \%$, fabrication and construction of traps $88.0 \%$, net maintenance $86.1 \%$, smoking oven $85.2 \%$ and construction of low cost gill netting $84.7 \%$. The result agreed with the findings of Oladoja et al. (2008) who opined that all these fishing technologies fall within the ambit of production activities. The implication of these is that the fishermen were current with the trend of government activities in improving their catches through extension agents. 
Table 1. Awareness of small scale fishermen on fishing technologies

\begin{tabular}{llll}
\hline $\mathbf{S} / \mathbf{N}$ & Variables & Yes-\% & No- $\%$ \\
\hline 1. & Fabrication of low cost fishing gears & $181-83.8$ & $35-16.2$ \\
2. & Smoking oven & $184-85.2$ & $32-14.8$ \\
3. & Net maintenance & $186-86.1$ & $30-13.9$ \\
4. & Construction of low cost gill netting & $183-84.7$ & $33-15.2$ \\
5. & Designing multiple look on a line & $195-90.3$ & $21-9.7$ \\
6. & Fabrication and construction of traps & $190-88.0$ & $26-12.0$ \\
7. & Outboard engine repairs & $182-84.3$ & $34-15.7$ \\
8. & Modern smoking kiln. & $183-84.7$ & $33-15.3$ \\
\hline
\end{tabular}

Source: Field survey (2013).

Table 2 indicates the level of training needs of fishermen, designing multiple hooks on a line $77.3 \%$, fabrication of low cost fishing gears $70.4 \%$, fabrication and construction of traps $67.6 \%$, and smoking oven $66.2 \%$. Ojukwu et al. (2011) reported about $91 \%$ of the fisher folk having high level of information need for improved fisheries technologies. Arowolo et al. (2012) suggested that unfelt but important training needs and those expressed by only a small proportion of the trainees should be indicated in the training exercise only after meeting the highly ranked ones. It is therefore the task of training Institutions/organizers to provide trainees with the opportunity to learn and stimulate mental and physical activity that produce desired learning (Oloruntoba \& Akinsorotan, 2012). It could be inferred that the fishermen showed interest on training of fishing technologies which could also assist them in improving on their income and welfare.

Table 2. Training needs of small scale fishermen on fishing technologies

\begin{tabular}{llll}
\hline S/N & Variables & Yes- $\%$ & No- $\%$ \\
\hline 1. & Fabrication of low cost fishing gears & $152-70.0$ & $64-29.6$ \\
2. & Smoking oven & $143-66.2$ & $73-33.8$ \\
3. & Net maintenance & $131-60.6$ & $85-39.4$ \\
4. & Construction of low cost gill netting & $139-64.6$ & $37-35.6$ \\
5. & Designing multiple hooks on a line & $167-77.3$ & $49-22.7$ \\
6. & Fabrication and construction of traps & $146-67.6$ & $70-32.4$ \\
7. & Outboard engine repairs & $125-57.9$ & $91-42.1$ \\
8. & Modern smoking kiln. & $130-62.2$ & $86-39.8$ \\
\hline
\end{tabular}

Source: Field survey (2013).

Table 3 shows the level of training needs of the small scale fishermen, $82.4 \%$ indicated favorable training needs in fishing technologies $16.7 \%$ indicated unfavorable training needs. The high level of training needs was an indication by the small scale fishermen to acquire modern fishing technologies to have improvement on their catches. There is high demand of fish consumption in the country, to be able to meet up fishermen needed adequate training on fishing technologies that would assist them.

Table 3. Training needs in fishing technologies

\begin{tabular}{lll}
\hline S/N & Level of training needs & Frequency $-\%$ \\
\hline 1. & Neutral & $2-9$ \\
2. & Unfavourable & $36-16.7$ \\
3. & Favourable & $178-82.4$ \\
\hline
\end{tabular}

Source: Field survey (2013).

Small scale fishermen indicate constraints experienced which is presented in Table 4, lack of proper net 
maintenance $76.9 \%$, limited outboard engine repair workshop $73.6 \%$, effective fish processing and preservation technologies and equipment $70.4 \%$, climate and tides $63.4 \%$ and lack of input/capital availability $61.1 \%$. The implication is that the durability of the net would be reduced if no proper net maintenance, fishermen may also resort to the use of paddle that is energy sapping and time consuming if they find it difficult to repair their outboard engines also, there would be a lot of post harvest losses resulting from problem of effective fish processing and preservation techniques and equipment.

Table 4. Constraints experienced by small scale fishermen on fishing

\begin{tabular}{lllll}
\hline $\mathbf{S} / \mathbf{N}$ & Variables & Yes- $\%$ & \multicolumn{2}{c}{ No- $\%$} \\
\hline 1. & Climate and tides & 13763.4 & 79 & 36.6 \\
2. & Effective fish processing and preservation techniques and equipment & 15270.4 & 64 & 29.6 \\
3. & Lack of proper net maintenance & 16676.9 & 50 & 23.1 \\
4. & Limited of outboard engine repair workshop & 15973.6 & 57 & 26.4 \\
5. & Lack of input/capital availability & 13261.1 & 84 & 38.9
\end{tabular}

Source: Field survey, 2013.

Relationship was determined between awareness of fishing technologies and the training needs of small scale fishermen (Table 5). At 0.05 level of significance, there were significant relationship between awareness and training needs on fabrication of low cost fishing gears $\left(\chi^{2}=18.48 ; \mathrm{p}<0.05\right)$, smoking oven $\left(\chi^{2}=15.77\right.$; $\mathrm{p}<$ $0.05)$, net maintenance $\left(\chi^{2}=3.90, p<0.04\right)$ construction of low cost gill netting $\left(\chi^{2}=4.53 ; \mathrm{p}<0.03\right)$, designing multiple hook on a line $\left(\chi^{2}=33.16 ; p<0.00\right)$, fabrication and construction of traps $\left(\chi^{2}=17.68, p<0.00\right)$, outboard engine repairs $\left(\chi^{2}=37.80 ; p<0.00\right)$ and modern smoking klin $\left(\chi^{2}=37.80, p<0.00\right)$. This implies that awareness of fishing technologies among small scale fishermen was with corresponding training needs. This is a good indication of development in the fishery subsector of the economy.

Table 5. Chi square relationships between awareness and training needs of small scale fishermen on fishing technologies

\begin{tabular}{llllll}
\hline S/N & Training variables & $\chi^{2}$ & Df & P & Remarks \\
\hline 1. & Fabrication of low cost fishing gears & 18.48 & 1 & 0.00 & Sig. \\
2. & Smoking oven & 15.77 & 1 & 0.00 & Sig. \\
3. & Net maintenance & 3.90 & 1 & 0.04 & Sig. \\
4. & Construction of low cost gill netting & 4.53 & 1 & 0.03 & Sig. \\
5. & Designing multiple hooks on a line & 33.16 & 1 & 0.00 & Sig. \\
6. & Fabrication and construction of traps & 17.68 & 1 & 0.00 & Sig. \\
7. & Outboard engine repairs & 5.47 & 1 & 0.01 & Sig. \\
8. & Modern smoking kiln. & 37.80 & 1 & 0.00 & Sig. \\
\hline
\end{tabular}

Source: Field survey, 2013.

\section{Conclusion and Recommendation}

There was high awareness of fishing technologies and training needs among small scale fishermen in the study area. From the results, it could be inferred that if the awareness process of various fishing technologies among the small scale fishermen is consistently backed up with adequate training the greater would be the improvement in the fishing activities resulting to higher productivity of small scale fishermen and availability of more protein for the consumption of the populace. The research also identified constraints faced by the fishermen in their fishing profession. These constraints include effective fishing processing and preservation techniques and equipment. Significant relationship exists between awareness and training needs for all the variables considered in the study area. 
Based on the findings of the study, it is recommended that concerted efforts should be made by all stakeholders to ensure that the required training needs of small scale fishermen are met. The extension agents or fisheries researchers should utilize training strategies or methods to deliver the needs of small scale fishermen in a way that the trainees will achieve the objectives of the training. For the training to be effective, regularity and proper timing should be considered so that the fishermen would be able to participate and profit maximally.

\section{Acknowledgements}

The author is indeed grateful to the Vice Chancellor and the Central Research Committee of the Ondo State University of Science Technology for funding this research.

\section{References}

Adeokun, O. A., \& Adereti, F. O. (2003). Agricultural Extension and Fishery Development: Training for Women in Fish industry in Lagos-State, Nigeria. Journal of Social Science, 11(1), 1-5.

Adeokun, O. A., Adereti, F. O., \& Opele, A. I. (2006). Factors Influencing Adoption of Fisheries Innovations by Artisanal Fishermen in Coastal Areas of Ogun State, Nigeria. Journalof Applied Sciences Research, 2(11), 966-971

Arowolo, O. O., Banmeke, T. O. A., \& Ajayi, T. M. (2012). Assessment of the Training Needs of Poultry Farmers in Ovia and Oredo Local Government Areas of Edo State, Nigeria. African Journal of Livestock Extension, 10, 23-30.

FAO COFI. (2005). Supporting Small-Scale Fisheries through an enabling environment. Committee on Fisheries, 26th Session, March 7-11, 2005. Rome, Italy

FAO. (2005). Fisheries and Aquaculture Issues Fact Sheet: Governance of small-scale fisheries. FAO, Rome.

Hauck, M. (2000). Review of Literature on Artisanal and Subsistence Fisheries. SFTG Report No 6. Unpublished Report, MCM. Cape Town.

O'Riordan, B. (2005). Sizing up the Scales of African Fisheries, towards defining small-scale and artisanal fisheries in Africa. ICSF, Draft Paper.

Okwu, O. J., Yahaya, M. A., \& Obinne, C. P. O. (2011). Analysis of Artisanal Fisher Folk Information needs and Accessibility in Benue State, Nigeria. Asian Journal of Agricultural Sciences, 3(5), 408-413.

Oladoja, M. A., Adedoyin, S. F., \& Adeokun, O. A. (2008). Training needs on Fisher folks on Fishing Technologies. Journal of Food-Agriculture and Environment, 6(1), 195-198.

Oloruntoba, A., \& Akinsorotan, A. O. (2010). Assessment of learning components of management training course for senior managers at the Agricultural Research Institutes of Nigeria. Moor Journal of Agricultural Research, 4(1), 140-148.

Sowman, M. (2004). Legal Terms in African Countries Defining Scales in Fisheries. Unpublished Report. Environmental Evaluation Unit, (UCT), Cape Town.

Sunde, J., \& Pedersen, C. (2007). Defining the Traditional Small Scale Fisheries Sector in South Africa. A Discussion Paper prepared by Masifundise and presented by Marine and Coastal Manage mental Affairs and Tourism. Discussion Series \# 1 (p. 8).

\section{Copyrights}

Copyright for this article is retained by the author(s), with first publication rights granted to the journal.

This is an open-access article distributed under the terms and conditions of the Creative Commons Attribution license (http://creativecommons.org/licenses/by/3.0/). 